\title{
The Effect of Using Self-Regulated Learning Strategies on Developing English Language Critical Reading Skills of Governmental Language Secondary Stage Students
}

\section{By}

\section{Mustafa Bahagat Younis Ismail}

\section{Introduction}

Considered as one of the main skills in learning a language, reading is classified by Adams (1990) as one of the most important processes that children should master to prosper in the modern world. The early development and acquisition of skills critical to reading is essential to children's long success.

Emphasizing the importance of reading, some educators think that having good readers is one of the aims of teaching reading at school. That is why both Mcshane (2005) and Alnujidi (2003) assured that good readers know to bring what they already know about a topic into reading about that topic. They fill in the gaps in the content to make inferences and determine the relationships of various parts of the passage to the whole. They use linguistic processes to identify the words that help them apprehend the text.

\footnotetext{
هذا البحث مقتبس من رسالة ماجستير وعنوانها اثر استخدام إستراتيجيات التعلم المنظم ذاتياً في تنمية مهارات القراءة الناقدة في اللغة الإنجليزية لدى طلاب الصف$$
\text { الأول الثانوي بمدارس اللغات التجريبية }
$$$$
\text { اعداد / مصطفى بهجات يونس اسماعيل }
$$$$
\text { إثراف }
$$$$
\text { المرحوم أ.د / عطا طه زيدان أستاذ المناهج وطرق تدريس اللغة الانجليزية - العميد الأسبق لكلية }
$$$$
\text { التربية بالمنيا - جامعة المنيا }
$$$$
\text { أ.د / محمد إسماعيل أبو رحمه أستاذ المناهج وطرق تدريس اللغة الانجليزية - الوكيل السابق لشئون }
$$$$
\text { الطلاب - كلية التربية بالإسماعيلية - جامعة قناة السويس تلانسين }
$$$$
\text { أ.م .د / طاهر محمد الهادي أستاذ المناهج وطرق تدريس اللغة الانجليزية المساعد - كلية التربية }
$$$$
\text { بالإسماعيلية - جامعة قناة السويس }
$$ 


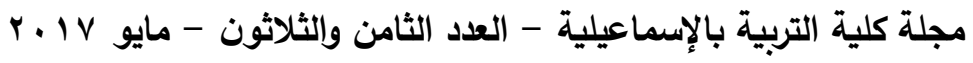

On the other hand, according to Briskin (2005), students often read a course text from beginning to end in order to prepare for class. Much of their dismay, they probably forget much of what they have read and are not really prepared to participate in discussion.

To classify the critical reading skills as some of the needed reading comprehension skills, Serag (2005) and Mohammad (1999) listed the reading comprehension skills as the following:

1. Literal reading comprehension skills.

2. Inference reading comprehension skills.

3. Critical reading comprehension skills.

Fadelelmula (2010) mentioned that learning should be based on learning strategies that enable students to monitor and control their learning process. In the same line of thought, Zimmerman (1989) stated that a self-regulated learner is met- cognitively, motivationally and behaviorally active in his/her own learning process. Also, El-Sayed (2009) stressed the characteristics of self-regulated learning strategies as follows:

1. These strategies are determined reactions that lead to achieving specific goals.

2. These strategies are generated by the learner and they include power and control instead of surrendering and following useless rules.

3. They are applied optionally and flexibly as they include cognitive skills, control and motivation.

4. They are considered as helpful plans to solve problems.

5. Although these strategies are considered important and effective plans for solving problems, they lead to automization.

To make it easy for students to use self-regulated learning strategies, Housand and Reis (2008) suggested that the teacher should model the self-regulated learning strategies to help students selfregulate their reading. Consequently, they can read for a long time and answer the questions that measure the high thinking levels. But Rahmy (2010) argued that EFL reading classrooms are characterized by anxiety and poor reading.

Iwai (2011) stated that a metacognitive teaching technique is utilizing graphic organizers, which are visual representations or illustrations that organize the information of a text. For example, they can be used for teaching expository text structures, including cause and effect, question and answer, simple listing, chronological order, compare and contrast, and description. Students who understand how a 
text is structured have better ideas about what information comes next, or what information they are expected to look for. It is important that teachers employ a variety of methods, appropriately selecting strategies in order to achieve specific goals.

\section{Review of Literature}

\section{Self-Regulated Learning}

There are many writers and educators who defined selfregulated learning. For example Zimmerman (2002) defined selfregulation as the self-directive process by which learners transform their mental abilities into academic skills. Therefore, according to Zimmerman, learning is viewed as an activity that students do for themselves in a proactive way rather than a covert event that happens to them in reaction to teaching.

Nuckles (2008) stated that self-regulated learning is "the ability to control and influence one's learning processes positively. The learners take initiative, apply powerful strategies to attain individually valued learning goals and monitor their understanding in order to detect and eliminate possible comprehension problems." Thus, learners are responsible for their learning process as stated by Boom (2007) who defined self-regulated learning as the active and constructive process that makes learners responsible for their own learning.

In the light of the previous definitions, it can be concluded that students are responsible for their own learning when they use selfregulated learning strategies as they transform and organize information rather than accept it as it is presented in the reading texts. They also ask questions and self-evaluate their learning progress. As a result, they become active learners and the tasks become studentcentered. Thus, self-regulation is an integrated learning process, consisting of the development of a set of constructive behaviors that affect one's learning. These processes are planned and adapted to support the pursuit of personal goals in changing learning environments.

\subsection{Self-regulated Learning Strategies}

Wang (2004, citing Pape \& Wang 2003) listed some selfregulated learning strategies as follows:

1. Organizing and transforming: Using these strategies, learners do self-initiated overt or covert rearrangement of instructional 


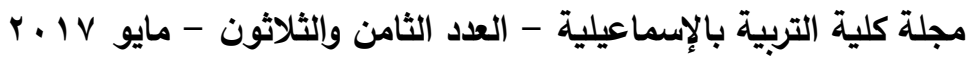

materials to improve learning as they draw concept maps of the main ideas in the reading passage.

2. Goal setting and planning: Learners set educational goals or sub-goals and plan for sequencing, timing and completing activities related to the self-set goals. They plan the time needed for reading a text.

3. Seeking information: Learners exert self-initiated efforts to secure further task information from nonsocial sources. Learners use dictionaries to look up difficult words to help them understand the reading passage.

4. Rehearsing and memorizing: Learners exert self-initiated efforts to memorize learning materials by overt or covert practice. Learners ask themselves some questions and make sure that they can answer them.

5. Seeking social assistance: Learners exert self-initiated efforts to solicit help from adults, teachers or peers. Learners ask their peers and teachers for help.

1.2. The Principles of Self- regulation:

Pintrich summarized the common underlying principles of selfregulation in Mezei (2008) as follows:

1. Self-regulation learning is pro-active and constructive, that is, the student is active in the learning process.

2. A prerequisite for self-regulated learning is the potential for control. The students are able to monitor the learning process, which is a function of certain individual differences.

3. In self-regulated learning there are goals, criteria and standards that help the learner to modify the process of learning if needed.

4. Mediators have an important role in self-regulated learning in that they are link between the learner and outer expectation, and between actual and expected activity.

\subsection{The Characteristics of Self-regulated Learners}

Mezei (2008) claimed that self- regulated learning is characterized by the following:

1. Learning is student-initiated and the students persistently carry out the task.

2. Students are autonomous. They use efficient learning strategies.

3. Students are able to reflect on their work.

4. Self-regulated learners are typically interested in learning, able to set intrinsic and personal goals, realistic about their own knowledge and love learning. They are also self-confident, 
diligent and persistent. Self-regulated learners also possess a wide range of adaptive motivational beliefs and attitudes which help them direct and control their learning.

\subsection{Self-regulated Learning Strategies Used by Critical Readers}

1. Organizing and transforming:

Organization is a learning strategy in which students divide the material into subsets and identify the relation between subsets. This strategy includes diagramming or creating network of important ideas. Learners use graphic organizers to transform information. Bates (2006) stated that graphic organizers are examples of transforming information. Graphic organizers are visual representations of information, usually in some type of diagram format.

2. Rehearsing:

Rehearsal strategies according to Bates (2006) are learning strategies that involve naming items from a list or reciting them to be learned. Bidjerano and Dai (2007) stated that rehearsal, the most basic learning strategy for processing of information, represents a verbal repetition of a material with the goal of memorization.

3. Self-evaluation:

Man-chih, (2006) stated that self-evaluation refers to students' perception of their current performance and comparison of previous performances. Students use the selfevaluation strategy to compare their current performance with the goal and to record their progress and what stages of motor learning they were in.

4. Seeking information:

Information seeking, according to Bates (2006), refers to the student's ability to seek from peers, teachers and other resources in order to clarify course material and to discover new information they would not learn on their own.

\section{Critical Reading}

Acott (1985) indicated that critical reading is aggressive reading; the reader uses specific skills and methods to evaluate and analyze a text, with cognition, or knowing what one has read, as the specific goals. Critical reading involves a composite of many 


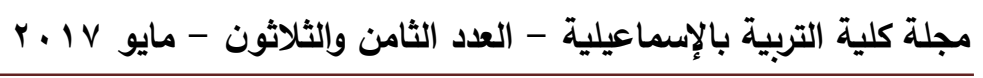

different skills and processes which might change depending on the type of material being read and the reason for reading it.

Norby (2009) defined critical reading as reading a text in such a way as to question assumptions, explore perspectives, and analyze underlying social and political values or stances. Critical reading is resistant, active, and focused on both the text and the world. Critical readers bring a range of experiences to texts, and, in turn, use texts to develop critical perspectives on personal and social experience.

\subsection{The Characteristics of Critical Learners}

Paul and Elder (2006) pointed out that students who think critically routinely read texts that are significant and thus expand their worldview. While reading, they consistently strive to accurately represent in their own thinking what they are reading in the text. Recognizing that every text has a purpose, they clarify the purpose of texts as they read them. Recognizing that close reading requires active engagement in reading, they create an inner dialogue with the text as they read as questioning, summarizing and connecting important ideas with other important ideas.

1. Students reflect as they read.

2. Students monitor how they are reading as they are reading and distinguishing between what they understand in the text and what they do not understand.

3. Students accurately summarize and elaborate texts in their own words as they read.

4. Students give examples from their experience using ideas in texts.

5. Students connect the core ideas in a text to other core ideas they understand.

6. Students take the core ideas they obtain through reading and apply them in their lives.

7. Students accurately paraphrase what they read sentence by sentence.

8. Students accurately and logically explicate the thesis of a paragraph.

9. Students analyze the logic of what they read; its purpose, its main question, the information it contains and its main idea.

10. Students evaluate what they read for clarity, accuracy, precision, relevance, depth, breadth, logic and significance and so forth. 
11. Students accurately role-play an author's viewpoint as presented in a text.

\section{Statement of the Problem}

Based on the previous studies, the general aims of teaching English in the secondary stage and the researcher's experience as a teacher of English at governmental language schools where students have to criticize some literary works such as English poetry and novel, it was noted that there are several difficulties in English critical reading skills of first year of experimental secondary school students. These difficulties may be due to the use of traditional learning strategies. Accordingly, the researcher tried to overcome the difficulties of those students and develop these critical reading skills by using some selfregulated learning strategies.

\section{Questions of the Study}

The current study tried to answer the following main question:

What is the effect of using self-regulated learning strategies on developing English language critical reading skills of first year governmental secondary school students?

The following sub-questions stated as follows:

1. What are the self-regulated learning strategies used to develop critical reading skills of first year governmental secondary school students?

2. What is the effect of using self-regulated learning strategies on developing English critical reading skills of first year governmental secondary school students?

\section{Hypothesis of the Study}

The following hypothesis has been formulated.

There is a statistically significant difference between the mean scores of the students on the pre-post critical reading sub skills test in favour of the post application.

\section{Aims of the study}

The present study aimed at developing English critical reading skills of first year experimental secondary school students through using some self-regulated learning strategies.

\section{Significance of the Study}

The present study seems to be beneficial for the stakeholders of teaching English as a foreign language in the following; 


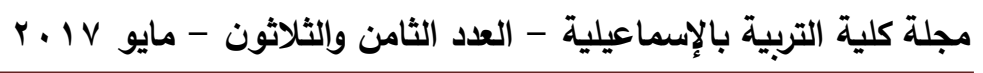

1. Developing English critical reading skills of first year experimental secondary school students.

2. Directing the supervisors' attention to training teachers of English on how to teach English language using self-regulated learning strategies.

3. Directing curriculum designers' attention to using self-regulated learning strategies while developing methods of teaching English.

4. Directing curriculum designers' attention to benefitting from integrating critical reading skills in secondary stage EFL courses.

\section{Delimitations of the Study}

The study was delimited to:

1. One class of the first year governmental secondary school students; (Class 1-C, 24 ${ }^{\text {th }}$ October Experimental Secondary School for Girls, Ismailia) namely 28 students.

2. Four self-regulated learning strategies namely; transforming and organizing strategy, self-evaluation strategy, rehearsing strategy and information seeking strategy.

3. Five critical reading skills of the first year experimental secondary school students namely identifying the author's purpose, drawing inferences based on cause/effect or evidence, summarizing parts of what they read in their own words, recognizing the likely effect of a writer's choice of words on conveying the writer's message and identifying the sequence of events or steps of processes

4. The second term of the academic year (2013/2014).

\section{Definition of Terms}

\section{Self-regulated Learning (SRL)}

The researcher adopted the following definition; Bates (2006) defined SRL as learning that results largely from the influence of students' self-generated thoughts, feeling, strategies and behaviors that are oriented toward obtaining goals.

\section{Critical Reading}

For critical reading skills, the researcher adopted Wolverton's (2008) definition which stated that critical reading comprehension is the author's message implicitly stated. Components of critical reading comprehension are recognizing author's purpose and tone identifying organizational patterns, 
recognizing the relationships between words, phrases and sentences, distinguishing between facts and opinions, detecting bias, recognizing valid/invalid arguments, and drawing inferences and conclusions.

\section{Method}

\section{Design and participants}

This study was a one group pre - post quasi -experimental design. It was conducted to investigate the effect of using self-regulated learning strategies on developing English critical reading skills of secondary school students. The experiment was carried out at $24^{\text {th }}$ October Experimental Language School, (Secondary Stage), Ismailia. The experiment was carried out through the second term of the academic year 2013/2014. The study group was trained on the use of four self-regulated learning strategies.

The participants of the study was chosen as an intact group from EFL classes of the first year school students at $24^{\text {th }}$ October Experimental Language School, Ismailia. The participants were twenty eight female students. They formed one pre-post group design. The choice of these participants was because the students were able to practice such self-regulated learning strategies as they study advanced level in English. They also study literature in the advanced level course and they need the critical reading skills to understand novel, poetry and drama.

\section{Hypothesis}

Based on the design above, the current study tried to verify the following hypothesis

There is a statistically significant difference between the mean scores of the students on the pre-post critical reading sub skills test in favour of the post application.

\section{Instruments of the Study}

The researcher prepared and used the following instruments:

1. A Self-Regulated Learning Strategies Checklist. (Developed by the researcher)

2. A Critical Reading Skills Checklist. (Developed by the researcher)

3. A Critical Reading Skills Achievement Test. (Developed by the researcher) 


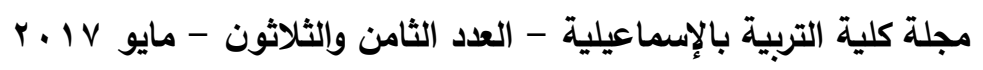

4. Suggested materials implementing the self-regulated learning strategies. (Developed by the researcher)

\section{The Critical Reading Skills Questionnaire (CRSQ)}

The main aim of this questionnaire was to specify the basic critical reading skills needed by first year secondary schoolers. This instrument was important because it is considered a basis for the critical reading skills test and the proposed self-regulated learning strategies lessons.

To specify the basic critical reading skills, related studies were surveyed. After the review of literature, the next step was initially preparing a checklist of critical reading skills. This checklist consisted primarily of fifteen skills These skills were validated by professors and supervisors who decided on choosing five critical reading skills as follows:

1. Identifying the author's purpose.

2. Drawing inferences based on cause/effect or evidence.

3. Summarizing parts of what they read in their own words.

4. Recognizing the likely effect of a writer's choice of words on conveying the writer's message.

5. Identifying the sequence of events or steps of processes Validity of CRSQ

To establish the validity of the questionnaire, it was presented to a jury of nine specialists in the field of TEFL to evaluate it. It was considered that $(\mathbf{7 5 \%})$ of the agreement among the jury members appropriate for accepting the item to be included in the critical reading skills questionnaire. To calculate the validity of the questionnaire, both the frequencies and the percentage were estimated.

\section{The self-regulated learning strategies (SRLS) checklist}

After reviewing the related studies, the researcher developed a checklist of four self-regulated learning strategies that may be suitable for first year secondary schoolers in the Egyptian context. The researcher aimed at identifying the suitable self-regulated learning strategies for students to be implemented in the suggested lessons. Based on the previous studies on self-regulated learning strategies used on developing learning English, the researcher decided on the following four strategies proposed by Wong (2005):

1. Transforming and Organizing Strategies

Learners use different methods including student-initiated rearrangement of instructional materials to improve learning. They use concept maps to visualize the learning materials. 
2. Seeking Information Strategies

Learners exert efforts to secure further task information from nonsocial sources such as magazines, reference books, internet, textbooks, notes, completed work, visits to relevant places when undertaking an assignment.

3. Rehearsing Strategies

Learners exert self-initiated efforts to make revision or practice exercises.

4. Self-evaluation Strategies:

Learners self- evaluate the quality or progress of their work.

\section{Internal Consistent Validity}

The correlation between the five critical reading skills and the total score was calculated. This kind of validity measures the correlation between the skills and the total score. The results were as follows:

Table 1: Internal Consistent Validity of the CRST:

\begin{tabular}{|r|l||c||}
\hline No & Skill & Correlation \\
\hline 1 & Identifying the author's purpose & $0.79(* *)$ \\
\hline 2 & $\begin{array}{l}\text { Drawing inferences based on cause/effect or } \\
\text { evidence }\end{array}$ & $0.81(* *)$ \\
\hline 3 & $\begin{array}{l}\text { Summarizing parts of what they read in their } \\
\text { own words }\end{array}$ & $\mathbf{0 . 7 6}(* *)$ \\
\hline 4 & $\begin{array}{l}\text { Recognizing the likely effect of a writer's choice } \\
\text { of words on conveying the writer's message }\end{array}$ & $\mathbf{0 . 8 9}(* *)$ \\
\hline 5 & $\begin{array}{l}\text { Identifying the sequence of events in a story or a } \\
\text { narrative text or steps of processes }\end{array}$ & $\mathbf{0 . 5 5}(* *)$ \\
\hline
\end{tabular}

$(* *)$ statistically significant at 0.01

The statistical findings of table (1) above indicate that all of the critical reading skills are statistically significant at $(0.01)$ level. These findings reveal the high internal consistency of the test. Hence, the validity of the pre/post critical reading skills test was proven. Reliability of the critical reading skills test:

The reliability of the reading comprehension test was calculated through (Cronbach's Alpha). The test consisted of 22 items (twenty two questions). The results were as follows:

Table 2: Reliability of the critical reading skills test (CRST): 
مجلة كلية التربية بالإسماعيلية - العدد الثامن والثثلاثون - مايو V r r r

\begin{tabular}{|c|l||c||c||}
\hline \hline No & Skill & Items & Alpha \\
\hline 1 & Identifying the author's purpose & $\mathbf{2}$ & 0.76 \\
\hline 2 & $\begin{array}{l}\text { Drawing inferences based on cause/effect } \\
\text { or evidence }\end{array}$ & 10 & 0.77 \\
\hline 3 & $\begin{array}{l}\text { Summarizing parts of what they read in } \\
\text { their own words }\end{array}$ & 3 & 0.72 \\
\hline 4 & $\begin{array}{l}\text { Recognizing the likely effect of a writer's } \\
\text { choice of words on conveying the writer's } \\
\text { message }\end{array}$ & 4 & 0.75 \\
\hline 5 & $\begin{array}{l}\text { Identifying the sequence of events or steps } \\
\text { of processes }\end{array}$ & 3 & 0.73 \\
\hline
\end{tabular}

The statistical findings of table (2) above indicate that the values of Alpha were between the lowest value and the highest value $(0.72$ and 0.77 ) and all values are less than the value of the total test $(0.80)$. So, it can be said that the test is reliable.

\section{Learning Materials}

Based on the suggested four self-regulated learning strategies and the target five critical reading skills, the researcher prepared lesson plans to teach the materials in Hello!7 for first year secondary school students. Two lessons entitled (lesson 3, Reading and lesson 4, Critical Thinking) are prepared in units from 10 to 13.

Aims of the suggested learning materials

This strategy aimed at developing five critical reading skills as well as self-regulated learning strategies for the first year secondary students in Ismailia. By the end of studying the suggested materials, students should be able to:

1. Identify the author's purpose.

2. Draw inferences based on cause/effect or evidence.

3. Summarize parts of what they read in their own words.

4. Recognize the likely effect of a writer's choice of words on conveying the writer's message.

5. Identify the sequence of events or steps of processes.

\section{Procedures of the experiment}

1. Validating the critical reading skills checklist and the critical reading skills test (CRST).

2. Choosing the participants of the study from first year experimental secondary school students (class 1/C). 
3. Introducing the components of the suggested learning materials to the class and building a rapport with them.

4. Administering the pre-critical reading skills test.

5. Teaching the suggested learning materials based on selfregulated learning strategies to the target class.

6. Applying the post- critical reading skills test on the target class.

7. Collecting data and reaching at results and conclusions.

8. Interpreting the results.

9. Presenting recommendations and suggestions for further studies.

\section{Results and Discussion}

\section{Results}

The paired samples t-test was used to investigate the hypothesis of the study which stated that "There is a statistically significant difference between the mean scores of the students on the pre and post test in favour of the post application." The results of the test are shown in the following table:

Table 3: Results Related t-test

\begin{tabular}{|c|c|c|c|c|c|c|}
\hline Skill & Group & Mean & $\begin{array}{c}\text { St. } \\
\text { deviation }\end{array}$ & df & $\begin{array}{c}\text { t- } \\
\text { value }\end{array}$ & Sig. \\
\hline \multirow{2}{*}{$\begin{array}{l}\text { 1- Identifying the } \\
\text { author's purpose }\end{array}$} & $\begin{array}{c}\text { Pre- } \\
\text { test }\end{array}$ & 3.86 & 2.74 & \multirow{2}{*}{54} & \multirow{2}{*}{-6.48} & \multirow{2}{*}{$\begin{array}{l}0.00 \\
\text { Sig }\end{array}$} \\
\hline & $\begin{array}{c}\text { Post- } \\
\text { test }\end{array}$ & 8.04 & 2.03 & & & \\
\hline \multirow{2}{*}{$\begin{array}{l}\text { 2- Drawing inferences } \\
\text { based on cause/effect or } \\
\text { evidence }\end{array}$} & $\begin{array}{c}\text { Pre- } \\
\text { test }\end{array}$ & 22.93 & 5.28 & \multirow{2}{*}{54} & \multirow{2}{*}{11.94} & \multirow{2}{*}{$\begin{array}{l}0.00 \\
\text { Sig }\end{array}$} \\
\hline & $\begin{array}{l}\text { Post- } \\
\text { test }\end{array}$ & 37.75 & 3.91 & & & \\
\hline \multirow{2}{*}{$\begin{array}{l}\text { 3- Summarizing parts } \\
\text { of what they read in } \\
\text { their own words }\end{array}$} & $\begin{array}{c}\text { Pre- } \\
\text { test }\end{array}$ & 3.86 & 2.92 & \multirow{2}{*}{54} & \multirow{2}{*}{-7.82} & \multirow{2}{*}{$\begin{array}{c}0.00 \\
\text { sig }\end{array}$} \\
\hline & $\begin{array}{c}\text { Post- } \\
\text { test }\end{array}$ & 10.04 & 2.99 & & & \\
\hline \multirow{2}{*}{$\begin{array}{l}\text { 4- Recognizing the } \\
\text { likely effect of a } \\
\text { writer's choice of } \\
\text { words on conveying the } \\
\text { writer's message }\end{array}$} & $\begin{array}{l}\text { Pre- } \\
\text { test }\end{array}$ & 6.07 & 4.99 & \multirow{2}{*}{54} & \multirow{2}{*}{-8.68} & \multirow{2}{*}{$\begin{array}{c}0.00 \\
\text { sig }\end{array}$} \\
\hline & $\begin{array}{l}\text { Post- } \\
\text { test }\end{array}$ & 16.07 & 3.49 & & & \\
\hline
\end{tabular}


مجلة كلية التربية بالإسماعيلية - العدد الثامن والثثلاثون - مايو Y r r r

\begin{tabular}{|c|c|c|c|c|c|c|}
\hline \multirow{2}{*}{$\begin{array}{l}\text { 5- Identifying the } \\
\text { sequence of events or } \\
\text { steps of processes }\end{array}$} & $\begin{array}{c}\text { Pre- } \\
\text { test }\end{array}$ & 9.46 & 3.20 & \multirow{2}{*}{54} & \multirow{2}{*}{ 5.87- } & \multirow{2}{*}{$\begin{array}{c}0.001 \\
\text { sig }\end{array}$} \\
\hline & $\begin{array}{c}\text { Post- } \\
\text { test }\end{array}$ & 13.54 & 1.79 & & & \\
\hline \multirow{2}{*}{ Total } & $\begin{array}{c}\text { Pre- } \\
\text { test }\end{array}$ & 46.14 & 13.95 & 54 & \multirow{2}{*}{11.86} & \multirow{2}{*}{$\begin{array}{c}0.001 \\
\text { sig }\end{array}$} \\
\hline & $\begin{array}{c}\text { Post- } \\
\text { test }\end{array}$ & 83.79 & 9.35 & 54 & & \\
\hline
\end{tabular}

(**) Significant at 0.01 level. Number of participants $=28$

Table (3) indicates that there is a significant difference in the study group's mean scores on the pre and post tests of critical reading skills in favor of the post test, and it is statistically significant $(t=11.68)$.To interpret the results for each skill, the researcher compared the mean scores. For the first skill which is identifying the author's purpose. In the pre-test the mean score was (3.86), whereas the mean score of the post-test was (8.04).which indicates a great improvement attributed to the self-regulated learning strategies (SRLSs).

For the second skill which is drawing inferences based on cause/effect or evidence. In the pre-test the mean score was (22.93), whereas the mean score of the post-test was (37.75).This reveals, also, an improvement in students' ability of detecting relationships between things and its effect on students' acquisition of skills.

In the pre-test the mean score of the third skill which is summarizing parts of what they read in their own words was (3.86) ,whereas the mean score of the post-test was (10.04).This indicates a progress in students' ability to summarize what they have read in their own words.

The fourth skill which is recognizing the likely effect of a writer's choice of words on conveying the writer's message also indicated improvement as the mean score of the pre test was (6.07) and the mean score of the post test was (16.07).

The fifth skill which is identifying the sequence of events or steps of processes was improved for the mean score of the pre test was (9.46) and the mean score of the post test was (13.54).This indicated progress in students' acquisition of skills.

The total of all skills also showed a progress as the mean score of the pre test was (46.14) and the mean score of the post test was (83.79). 
Therefore, it was concluded that the SRLSs significantly improved the critical reading skills of the participants of the study.

Results Related to the Effect Size Calculations

The effect size calculation was used to investigate the effect size of the four self-regulated strategies on students' critical reading skills. The results of the test were shown in the following formula: The effect size: $\eta^{2}=\frac{T^{2}}{T^{2}+d f} \quad \eta^{2}=$ Eta square

$t=$ the $t$ value of the critical reading skills test

df $=$ degree of freedom $=\mathrm{N}-1$

Table 4: The effect size of the critical reading skills test:

\begin{tabular}{|c|c|c|c|c|c|}
\hline $\begin{array}{c}\text { Independent } \\
\text { Variable }\end{array}$ & $\begin{array}{c}\text { Dependent } \\
\text { Variable }\end{array}$ & t-value & Df & $\eta^{2}$ & $\begin{array}{c}\text { E-S } \\
\text { level }\end{array}$ \\
\hline SRLSs & $\begin{array}{c}\text { Critical } \\
\text { Reading } \\
\text { skills }\end{array}$ & 11.68 & 27 & 0.83 & Large \\
\hline
\end{tabular}

Table (5) indicated that the SRLSs yielded a large and substantial effect size $=\mathbf{0 . 8 3}$. So $83 \%$ of improvement in students' performance is due to the administering of the SRLSs. So the strategy was effective.

\section{Discussion of the study results}

The results of the present study showed that the study group indicated more improvement on the post administration of the critical reading skills test compared to the pre -test. Hence, the significant differences which were found to be on the post test favoring the post administration may be due to exposing the group to SRLSs which proved to be effective. This result supports the results of Petris (2008) and Wolverton (2008) who showed the effect of using self-regulated learning in teaching critical reading skills. It is also consistent with the results of Khajavi and Ketabi (2012) who stated that students in the concept mapping group showed greater achievement in reading 
مجلة كلية التربية بالإسماعيلية - العدد الثامن والثلاثون - مايو PV r.

comprehension and self-efficacy than students in the traditional method strategy group.

The results of the present study revealed the significance at (0.01) between the mean scores of the study group in developing critical reading skills in favor of their mean scores on the post test. This improvement may be due to the fact that while using SRLSs. Students were interested in practicing the critical reading activities because the learning environment was non-threatening and it provided them with enough opportunity to interact freely in the class room with the teacher (the researcher) and, also with their colleagues. This result supports the idea of Xiao (2006) and Wilawan (2012) who stated that formulating questions helps students understand the purpose of the reading more clearly as well as enhancing their critical thinking skills.

It can be stated that the improvement occurred in the study group's critical reading skills as a result of the experimental work which was used after administering the pre-test. The participants practiced the critical reading skills through using SRLSs activities including concept maps, asking self questions, doing self-evaluations that increased their ability to identify good points and to improve their retention of the material.

The self-regulated learning activities used in this study demonstrated more benefits in stimulating critical reading. As the activities designed such as, constructing concept maps were helpful. This supports the findings of Manoli and Papadopoulou (2012) and Iwai (2011) who assured the effectiveness of graphic organizers as a strategy for teaching English. Graphic organizers proved to be effective on summarization. It can be concluded that, the present study proved that using SRLSs is effective in developing critical reading skills for secondary school students.

\section{Conclusions}

Based on the findings of the current study, it was concluded that:

1. Self-regulated learning strategies proved to have an effect on enhancing secondary school students' critical reading skills as students, after experimentation, became able to read and understand reading texts effectively.

2. Also, self-regulated learning strategies enabled secondary school students to develop critical reading skills such as identifying the author's purpose, drawing inferences based on cause/effect or 
evidence, summarizing parts of what they read in their own words, recognizing the likely effect of a writer's choice of words on conveying the writer's message and identifying the sequence of events or steps of processes.

3. Self-regulated learning motivated students and encouraged them to interact and participate effectively in the various classroom reading activities.

\section{Recommendations}

Based on the findings and conclusions of the current study, the following are recommended:

1. Teachers should help students in secondary stage to develop their higher-order thinking skills.

2. Teachers should help students interact with the reading texts and try to infer and deduce the ideas embedded in the reading texts.

3. Teachers of EFL should prepare the reading activities that encourage students to self-regulate their learning and activate their critical reading strategies.

4. Textbook authors and designers should include some reading tasks and activities in reading books that foster students' critical reading skills.

5. Self-regulated learning strategies should be used by English language teachers in the teaching of reading.

6. Self-regulated learning strategies should be a component of the prescribed curriculum of English classes in different stages.

7. EFL secondary school students should be taught by these strategies to improve their critical reading comprehension skills.

Suggestions for further studies

Further research might be conducted on:

1. The effect of self-regulated learning strategies on developing secondary school students' critical writing skills as well.

2. The effect of self-regulated learning on preparatory school pupils' reading skills.

3. Investigating the effectiveness of (SRLSs) in increasing student's proficiency in English and improving their attitudes towards English language.

4. Further research is needed to investigate the effectiveness of using self-regulated learning in understanding grammatical rules. 


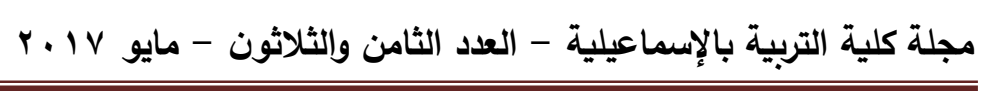

5. Further research should be done on the effect of teaching by selfregulated learning strategies on problem solving and decision making.

6. Further research should be recommended on the role of selfregulated learning in developing vocabulary.

7. A comparative study is needed to test the impact of selfregulated learning instruction on good comprehenders versus bad comprehenders. 


\section{References}

Acott, J. N. (1985). The Promotion of Critical Reading Skills in the High Schools. Language Arts Journal of Michigan, 1(1), $\begin{array}{llll}\text { Article } & 5 . & \text { Retrieved }\end{array}$ http://scholarworks.gvsu.edu/lajm/vol1/iss1/5

Adams, M. J. (1990). Beginning to Read: Thinking and Learning about Print, Cambridge: MIT Press.

Al-Nujidi, A. H. (2003). The Relationship Between Vocabulary Size, Reading Strategies and Reading Comprehension of EFL Learners in Saudi Arabia, PhD, Oklahoma State University. Retrieved from ProQuest database (ID No. 765986091).

Bates, C. (2006). The Effects of Self-regulated Learning Strategies on Achievement, Control Beliefs about Learning and Intrinsic Goal Orientation, PhD, College of Education, University of South Alabama.

Bidjerano, T., \& Dai, D. (2007).The Relationship Between the Big-Five Model of Personality and Self-regulated Learning Strategies. Learning and Individual Differences, 17, 69-81.

Boom, et al. (2007). Effects of Elicited Reflections Combined with Tutor or Peer Feedback on Self-regulated Learning and Learning Outcomes. Learning and Instruction, 17, 532548.

Briskin, L. (2005). A Guide to Active Reading and Asking Questions: A Handout for Students. Retrieved April, 20, 2011 from: http://www.arts.yorku.ca/sosc/ Foundations/documents/ActiveReading.pdf.

Fadelelmula, F. K. (2010). How a Learner Self-Regulates Reading Comprehension: A Case Study for Graduate Level Reading. U.S. China Educational Review. 10 (7), 22-28.

Housand, A., \& Reis, S. M. (2008). Self-regulated Learning in Reading: Gifted Pedagogy Instructional Settings. Journal of Advanced Academics, 1 (20), 108- 136.

Iwai, Y. (2011). The Effects of Metacognitive Reading Strategies: Pedagogical Implications for EFL/ESL Teachers, The Reading Matrix Volume 11( 2), 150 - 159.

Khajavi, Y., \& Ketabi, S. (2012). Influencing EFL Learners' Reading Comprehension and Self-efficacy Beliefs: The Effect of Concept Mapping Strategy. Porta Linguram 17, 2 , 9-27. 
مجلة كلية التربية بالإسماعيلية - العدد الثامن والثلاثون - مايو IV P P

Macshane, S. (2005). Applying Research in Reading Instruction for Adults. National Institute for Literacy, Washington DC.

Man-chih, A. (2006). The Effect of the Use of Self-regulated Learning Strategies on College Students' Performance and Satisfaction in Physical Education ,PhD, Australian Catholic University

Manoli, P., \& Papadopoulou, M. (2012). Graphic Organizers as a Reading Strategy: Research Findings and Issues. Creative Education, 3,(3), 348-356.

Mezei, G. (2008). Motivation and Self-Regulated Learning: A Case

Study of a Pre-Intermediate and an Upper-Intermediate Adult Student. WoPaLP, 2, 79 - 104.

Mohammad, A. (1999). What do We Test When We Test Reading Comprehension? The Internet TESL Journal, 12 (5). Retrieved from http:// itesl jorg/techniques/Mohammed testing Reading. html (Retrieved: April 4, 2011).

Norby, V. (2009). Critical Thinking, Reading and Writing: Transitioning High School Students from Casual Written Responses Toward Critical Analyses of Literature, MA, Sierra Nevada College.

Nuckles, M. et al (2009). Enhancing Self-Regulated Learning by Writing Learning Protocols. Learning and Instruction, 19, 259- 271.

Paul, R., \& Elder, L. (2006). The International Critical Thinking Reading \& Writing Test: How Assess Close Reading and Substantive Writing, Foundation of Critical Thinking. Retrieved from www.criticalthinking.org.

Petris, A.(2008). Developing Reading Comprehension Skills in Third Grade Students through the Modeling of Higher Order Critical Thinking Questions, MA, Caldwell College.

Rahmy, A. et al (2010). Teaching Reading with a Critical Attitude: Using Critical Discourse Analysis (CDA) To Raise EFL University Students' Critical Language Awareness (CLA). International Journal of Criminology and Sociological Theory, 2(3). 457- 476.

Serag, N. (2005). Training in Language Learning Indirect Strategies and Effectiveness in Enhancing Reading Comprehension Skills and Strategy Awareness. Journal of Mansoura, Faculty of Education,44(6), 42- 68. 
Wang, C. (2004). Self-Regulated Learning Strategies and Self-Efficacy Beliefs of Children Learning English as a Second Language. PhD, The Ohio State university.

Wilawan, S. (2012). Fostering Main Idea Comprehension among EFL Learners through Cognitive and Metacognitive Strategies. International Journal of Humanities and Social Science, 2 (14), 46 - 54.

Wolverton, L. (2008). Self-Regulated Learning Strategies of Successful Developmental Reading Students, PhD, Capella University.

Wong, M. (2005). Self-Regulation of Learning: Exploring the SelfRegulated Learning Practices of Pre-Service Teachers ,3rd International Seminar on Learning and Motivation , 10-12 September 2005, Pulau Langkawi, Kedah Darul Aman, Malaysia. Retrieved from the Eric database. (ED515054)

Xiao, L. (2006). How Goal Orientations, Perceived Competence, and Strategy Training Affect College Student's Use of SelfRegulated Learning Strategies and Achievement in Learning Foreign Languages, PhD, College of Education. Retrieved from the Eric database. (UMI Number: $3216561)$

Zimmerman, B.J (1989). Models of Self-Regulated Learning and Academic Achievement. Educational Psychologist, 25(1), 3-17.

Zimmerman, B.J. (2002). Becoming A Self-Regulated Learner: An Overview, Theory into practice,41(2), 64 - 70.

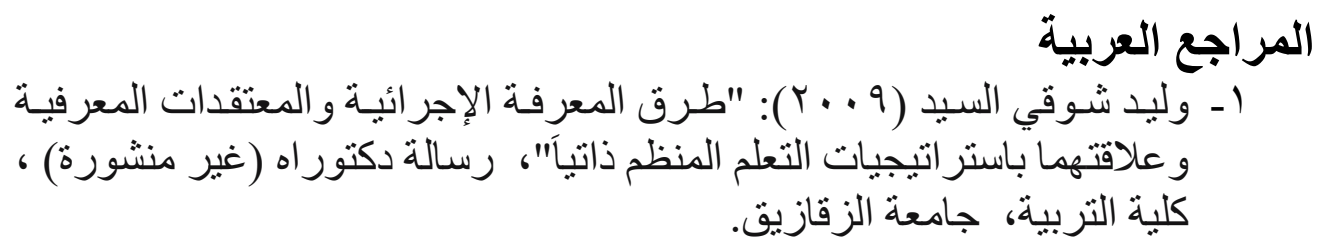




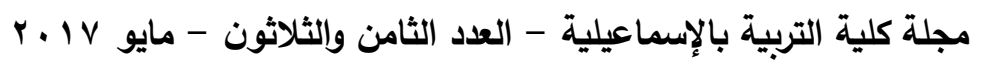

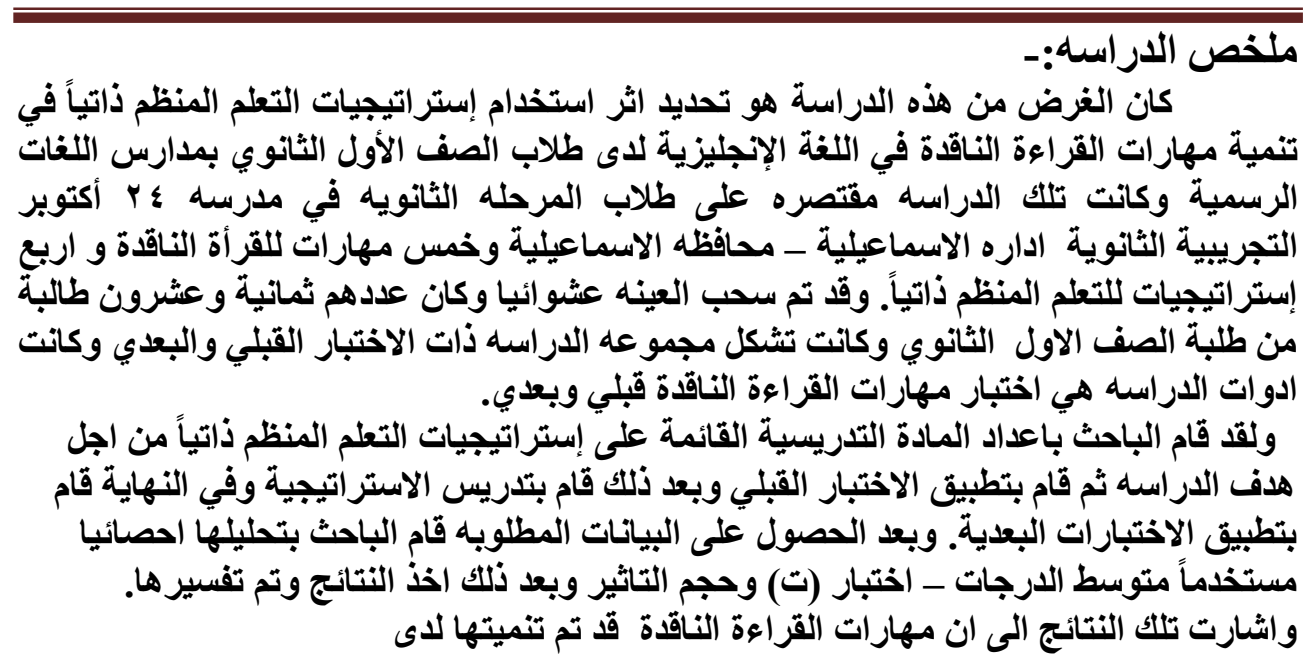

The ultimate aim of the present study was to investigate the effect of using self-regulated learning strategies on developing some English critical reading skills for first year secondary school students. The participants of the study were 28 EFL students at 24th Governmental Language Secondary School in Ismailia. They constituted a one group pre-post test design. They were taught using self-regulated learning strategies (SRLSs) which included eight sessions developed and taught by the researcher. Data were obtained from administering a critical reading skills test which included items measuring how much students acquired these skills. The data were analyzed statistically through the use of Cronbach's Alpha, t-test for paired samples, internal consistent validity and effect size (ES). The results of the students' critical reading skills test were fairly high. This revealed that the implemented self-regulated learning strategies had a significantly positive effect on developing the critical reading skills in English for secondary school students.

Key words: English Language Teaching (ELT), self-regulated learning strategies, critical reading skills, Governmental Secondary Schools, Egypt. 